\title{
Dialectic of Pornographic Enlightenment
}

\author{
Jörg Metelmann \\ University of St. Gallen \\ Department of Humanities and Social Sciences \\ Gatterstrasse 1 \\ CH-9000 St. Gallen \\ Switzerland \\ joerg.metelmann@unisg.ch
}

\begin{abstract}
This article introduces a dialectic of pornographic enlightenment through a reading of diaries written by the German avant-garde poet R. D. Brinkmann, and unfolds this basic pattern of modernity both systematically and historically with reference to Adorno and Horkheimer and the history of pornography. The framing of societal negotiations of pornography as a ceaseless shifting between the promise of liberation of and through sexuality and the fear of desensitization and loss of intimacy results in some comments on everyday life in "on/scenity" (Williams) and young people's identity politics ("Generation Porno") in pornographied pop cultures.
\end{abstract}

Keywords: critical theory, cultural logic, dialectic of desire, generation porn, history of sex, on/scenity, pornography.

\section{1....But When Did All This Start?}

The famous avant-garde poet Rolf Dieter Brinkmann (1940-1975) - considered the founder of the (West) German literary genre of "pop literature" as a combination of Anglo-American pop culture, music, art and the groundbreaking reformulation of narrative and aesthetic standards in poetry and literature as such - had an obsessive exchange with what is today called the "sexualization of culture" (Attwood, 2006, 2007). In his novels (e.g., Keiner weiß mehr, 1968), his poems and excessively so in his diaries (quoted below is his masterpiece Erkundungen für die Präzisierung des Gefühls für einen Aufstand: Reise Zeit Magazin [Tagebuch], written in 1971) he frankly described the invasion of sexual content and pornographic images into the societal imaginary and its impact on his own consciousness and desires. 
Got up: 5 past 4 p.m., ate 1 piece of cake, raisin cake/ 3 pots of coffee by quarter past 5 and working on travel diary Münster, letter from Pieper, shaved, went shopping: paperback Prostitution USA + Playboy with picture story Sex 1971 + Spiegel with cover story: the business of pornography=15.60DM. (:everything with Sex!) // Tuesday, November 2, 1971 (Brinkmann, 1987: $189)^{1}$

Brinkmann, who tragically died in a car accident after a lecture in Stratford-upon-Avon, did not claim a position of critical distance from this increase in sexual stimuli; on the contrary he openly surrendered to his drives and sometimes rather practically transformed them into immediate action:

/buy 2 packets of cigarettes, Emir-Orient without filter+Stuyvesant with=2,$\mathrm{DM} /$ big boobs come into my mind: go to a brothel to a woman with big tits=20,-DM/dialogue:you come in?what do ya take?twenty!do you do it with your hand?why?'cause I like that better!yes./not a word too much./ hang up coat without words, pass over the note which is put into a shoe box that is filled with notes (=images, that's how grandmother once called money in a letter, cautiously and anxiously, not stupid:money/=image!). I sit down, she slips over the rubber and starts, the constant sound of her hands rubbing the rubber, fitsch, fitsch, fitsch, gets her boobs out, shivers because of the cold fingers/dialogue:cold?:Yes./What do I see, I'm asking myself? I don't see this woman. But what do I see??? // Saturday, October 30, 1971 (Brinkmann, 1987: 188). ${ }^{2}$

What might, on the face of it, look like a rather typical example of 1960s and 70s "free your desire" sexual revolt against the prudery of the post-war period, is in fact a rather complex reflection on the state of mind of a sensitive artist driven by his perceptions, memories and desires. The fading of imagination and phantasy, the entanglement of sex, economy and prostitution, and his personal history and the reality

1. "Aufgestanden: 5 nach 4 nachmittags, 1 Stück Kuchen gegessen, Rosinenkuchen/3 Kännchen Kaffee bis 1/4 nach 5 und an Reisetagebuch Münster geschrieben, Brief von Pieper, rasiert, eingekauft: Taschenbuch Prostitution USA+Playboy mit Bildbeitrag Sex 1971+Spiegel mit Titelgeschichte: das Geschäft mit der Pornografie=15.60DM (:alles mit Sex!)//" (all translations from the German by Jörg Metelmann).

2. " "/kaufe 2 Schachteln Zigaretten,Emir-Orient ohne Filter+Stuyvesant mit=2.$\mathrm{DM} / \mathrm{mir}$ fallen dicke Brüste ein: gehe ins Bordell zu einer Frau mit dicken Titten=20.DM/Dialog:kommste rein? Wieviel nimmste? Zwanzig! Machste mit der Hand? Warum? Weil ich das lieber mag! Ja./Kein Wort zuviel./Ohne Worte Mantel aufgehängt, gebe den Schein, der in einen Schuhkarton gesteckt wird, der voller Scheine (=Bilder, wie die Großmutter einmal das Geld in einem Brief vorsichtig und ängstlich bezeichnete, nicht dumm:Geld/=Bild!) war. Setze mich, sie zieht das Gummi über und fängt an, das gleichmäßige Geräusch der reibenden Finger über dem Gummi, fitsch, fitsch, fitsch, sie holt ihre Brüste raus, schüttelt sich wegen der kalten Finger/ Dialog:ist kalt?: Ja./Was sehe ich, frage ich mich? Ich sehe diese Frau nicht. Aber was sehe ich???" 
of his own wishes ("I don't see this woman. But what do I see???") condensed into a highly intense situation, which can be seen as prefiguring the now commonly approved practice of "talking sex," public discourse on sexuality, gender and the economies and cultures of intimacy (and, one may add, the crisis of masculinity).

But for Brinkmann it was not easy at the time. Living in a family with a wife and a son, constantly questioning the nature of that relationship and its sexual negotiations and agreements - "in the kitchen talking with M., I see her crossed thighs, I think of fucking, I say 'fuck'/ dialogue: I want to fuck you. I' $m$ not your rubber!: then I get me another rubber!/" (Brinkmann, 1987: 189)3 - he moved within a triangle of traditional sexual coding (sex as procreation), a liberated and pornographic imaginary and his personal wish to fully understand (i.e., write down) what was going on.

(1) The negation in my head is so big that I even negate the lust that's offered to me and that rises in me, because I can see how again and again it gets on the old tracks, inevitably through women that, however veiled, carry out one and the same business: luring with the cunt, keeping one running, and running means: rabotti, rabotti, work, work, and behind it there's social prestige (masked as "but that's only human") and behind the prestige is preservation of the species, and now everything gets confused, kiosks oozing with yellow, rosy, red and brown titscumcuntspictures, advertisement, supermarkets, psychosomatic death stands at the end.

(2) What is to be put against this???

(3) Women/=Sex/=reproduction is not my fuel, but then what??? Lust??

(4) What could that mean, "the stars within us," Bertrand Russell, Battle For The Mind??/ then also sex has to be taken apart.

Thursday/Friday, November 4-5, 1971 (Brinkmann, 1987: 207). ${ }^{4}$

The imperative "then also sex has to be taken apart" hints, among other binary oppositions, at the fundamental opposition between women/ sex/reproduction and lust. "Lust," though heavily question marked by

3. "in Küche reden mit M. sehe ihre übereinandergeschlagenen Oberschenkel, denke an ficken, sage 'ficken'/Dialog: ich möchte dich ficken: Ich bin nicht dein Gummi!: dann hol ich mir eben ein anderes Gummi./"

4. “(1) Meine Negation im Kopf ist so groß, daß ich sogar die Lust negiere, die mir angeboten wird und die in mir hochsteigt, da ich sehen kann, wie sie immer wieder in die alten Gleise kommt, zwangsläufig durch Frauen, die, wie verschleiert auch immer, ein-und-dasselbe Geschäft betreiben: mit der Fotze ködern, einen am Laufen zu halten, und das Laufen heißt: rabotti, rabotti, arbeiten, arbeiten, und dahinter steht soziales Prestige (getarnt als 'ist doch menschlich!') und hinter dem Prestige steht die Arterhaltung, und nun geht alles wild durcheinander, Kioske triefen vor gelben, rosafarbenen, roten und braunen TittencumFotzenbildern, Werbung, Supermärkte, der psychosomatische Tod steht am Ende. (2) Was ist dagegen zu setzen??? (3) Frauen/=Sex/=Fortpflanzung ist nicht mein Treibstoff, was dann??? Lust?? (4): Was das heißen könnte, 'die Sterne sind in uns,' Bertrand Russell, Battle For The Mind??/Dann muss man aber auch den Sex auseinandernehmen." 
the author, seems to open the doors to a pure and unrestricted realm of pleasure and joy that the demands of nature incarnated in "women" as nature ("it's only human!") shut close right in front of the spectator's eyes. If "lust" can thus be understood as the realm of free sexual desire, pornography in its more publicly exposed and available forms ("titscumcuntpictures") can be seen as the vehicle of this phantasma, as the fiction that "sex simply exists" (Vinken, 1995: 16).

What Brinkmann somewhat despairingly describes is the concise articulation of a dialectic of pornographic enlightenment that moves back and forth between two poles: the promise of liberation and the fear of desensitivization. On the one hand, Brinkmann perceives pornography as a possible tool to overcome the unappealing (and quite misogynistic, one has to add) attractions of "women/=nature/=reproduction," but, on the other hand, he is not quite sure ("what is my fuel?") whether the consequence would not be the subject's total loss of all sensorial and sensual qualities ("psychosomatic death").

As I will argue in this article, Brinkmann is not the first to find himself bound (or even trapped?) in this dialectic. First, and with a systematic interest, I want to trace the concept of a "dialectic of enlightenment" with regards to pornography back to Theodor W. Adorno and Max Horkheimer, who coined the term, and their seminal study written in the early 1940s. Secondly, from a historical perspective, my aim is to briefly show how this dialectic evolved in modern times (1800-2000) after the "invention of pornography" (Hunt, 1996) in the context of the French Revolution.

\section{The Dialectic of Pornographic Enlightenment or Pleasure and Modernity}

Referring to "philosophical fragments" (the German subtitle of Adorno and Horkheimer's Dialectic of Enlightenment) also means to claim a third position when talking about pornography as the link between pleasure and modernity-one that has been neglected because of the overwhelming impact of Foucault's historical, and Freud's and Lacan's psychoanalytical, approach (most prominently of course through the work of Linda Williams and her combinations of both approaches in her studies of pornography). Though there is of course some Freud in the arguments of the two German philosophers, the strength of their argumentation (and their weakness in the development of philosophical debates after the linguistic turn that questioned the mind-paradigm) is their focus on the relation between mind (as consciousness, not language) and nature; or, more concretely in our context, of reason and body/pleasure. 
Adorno and Horkheimer's concept of the dialectic of enlightenment is twofold. It refers to a general mode of culture as such, and to the historical era of the Enlightenment in the eighteenth century. In their first chapter on the "concept of enlightenment" they define a broad notion of the term as involving the aim to liberate human beings "from fear and establish their sovereignty" (Adorno and Horkheimer, 2008: 3). The program was and still is the "disenchantment of the world; the dissolution of myths and the substitution of knowledge for fancy." This program connects enlightenment with liberty and social progress. But the authors-facing fascism and totalitarianism in Europe from their American exile-state a fundamental dialectic in this process between the formalization of rationality and the self-destruction of reason when "paralyzed by fear of the truth" (2008: xiv). "Truth" in their understanding is thus "merely the rational consciousness but equally the form that consciousness assumes in actual life" (2008: xiv). In this understanding of the concept of a dialectic of enlightenment, Ulysses and Hitler work in the same dialectical system with their slaves.

\section{Adorno/ Horkheimer: Dialectic of Enlightenment}

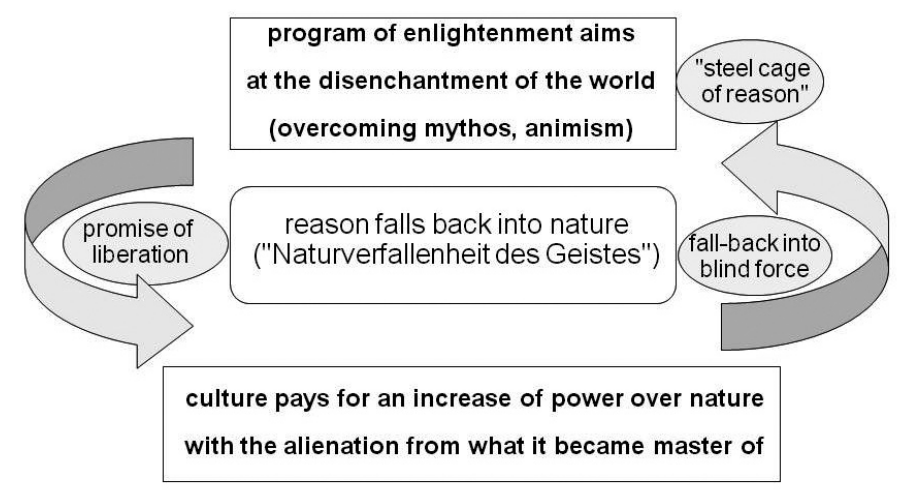

Quelle: Adorno, Theodor W/Horkheimer, Max: Dialektik der Aufklärung. Philosophische Fragmente, Neuausgabe Ffm 1969 (1944), pp. $19 / 25$

Adorno and Horkheimer's second use of the term "enlightenment" is closely linked to the age of the Enlightenment and it focuses on a discussion of the deformation of reason in Kant's philosophy and its impact on de Sade's pornographic philosophy. The Enlightenment of the eighteenth century subjected thinking to a process of self-preservation against nature (Adorno and Horkheimer, 2008: 87). De Sade spelled out the consequences of this use of reason against nature, through which it becomes nature itself (the famous "Naturverfallenheit des Geistes" / 
"subjugation of nature without which spirit does not exist" - 2008: 39). The battle between Justine and Juliette is unfair right from the beginning as the latter gains pleasure from beating civilization with its own rational instruments. But something backfires from the lascivious fouling of the sacrament.

Despite all her rationalism, Juliette is still somewhat superstitious. She sees the childishness of the sacrilege, yet in the end derives pleasure from it. But every indulgence betrays an idol: pleasure is self-sacrifice to another. Nature does not feature enjoyment as such; natural pleasure does not go beyond the appeasement of need. All pleasure is social-in unsublimated no less than in sublimated emotions. It originates in alienation... Men sense the magic of enjoyment only in that dream which releases them from the pressure of work and the bond which joins the individual to a specific social function and, ultimately, to the self... Thought originated in the course of liberation from a terrifying nature, which was finally wholly mastered. Pleasure is, so to speak, nature's revenge (2008: 104-105).

Interpreting texts from around 1800, these sentences in the Dialectic of Enlightenment also seem to be valid for Brinkmann's situation in the 1970s: the link between lust and society, social status, the pressure of work and the annihilation of enjoyment, the sensation of alienation when relying on pleasure as fuel. But there is still more to be found in Adorno and Horkheimer's work. Though they are not explicitly talking about pornography, their comments contain the nucleus of a specific dialectic of pornographic enlightenment that connects both (visual) pleasure and love, lust and intimacy, hard and soft-core pleasure and the socially accepted use of the senses in an exciting relationship.

What is true in all this is the insight into the dissociation of love, the work of progress. This dissociation, which mechanizes pleasure and distorts longing into deceit attacks the core of love. By praising genital and perverted sex to the disadvantage of unnatural, immaterial, and illusionary sexuality, the libertine throws herself in with that normality that belittles and diminishes not only the utopian exuberance of love but its physical pleasure, not only the happiness of the seventh heaven but that of the immediate reality. The rake without illusions (whom Juliette stands for) transforms himself with the assistance of sex educators, psychoanalysts, and hormone physiologists into the open and practical man who extends his attitude to sport and hygiene to his sexual life. Juliette's critique is discordant, like the Enlightenment itself. In so far as the flagrant violation of the taboo, which was once allied to the bourgeois revolution, has not adjusted proficiently to the new reality, it lives on with sublime love as faith in that now proximate utopia which makes sexual pleasure free for all (Adorno and Horkheimer, 2008: 109).

In this extremely rich and future-oriented passage I see three main elements for a dialectic of pornographic enlightenment, understood as a basic shift within the social negotiation of pornography between the promise of sexual liberation and the fear of desensitization. 
First, Adorno and Horkheimer identify as the core dynamic of that dialectic the impact of a mechanization of lust on the notion and perception of love, more precisely romantic love. Libertines have accused this love of being "a disguise, a rationalization of physical impulse, 'a false and always dangerous metaphysics'" (Adorno and Horkheimer, 2008: 108). But for Adorno and Horkheimer romantic love is still powerful as a higher concept of love that cannot be reduced to the act of sex, and furthermore as incorporating a whole tradition of physical experience. The notion of tenderness as "transformed sexuality" (2008: 108) - linking kiss to coitus - is also the basic idea of Linda Williams's book, Screening Sex (2008), in which she suggests a "dialectic between revelation and concealment that operates at any given moment in the history of moving-image sex" (Williams, 2008: 7), though she does not refer to the tradition of dialectic discussed here. Due to their philosophical approach - a critique of de Sade's pornographic philosophy against the background of reason's eclipse-Adorno and Horkheimer do not see pornography's potential for liberation, for opposing, for example, the "new ideals of domesticity that were developing in the eighteenth and nineteenth century" (Hunt, 1996: 45). But it is this intertwining of liberation and pornography that is at work in the proto-feminist images of women to be found in novels like de Sade's Thérèse philosophe or Margot la ravaudeuse, or in Salman Rushdie's desire to distribute pornographic films in the Islamic world in support of its critical youth (Rushdie, 2004). Maintaining this critical and very political function of early pornography (Hunt, 1996: 41-43) as a central element of the dialectic of enlightenment, we can describe the cultural processes of pleasure and modernity as alternations between disembedded sex (= pornography as the fiction that sex simply exists) and re-embedded sex (with a range of expressions, from an equilibrium between lust and tenderness to the cultural restriction of libido, as in Victorianism).

Secondly, Adorno and Horkheimer somehow anticipated Foucault's care of the self (souci de soi) as the responsible organization of one's sex life ("the open and practical man who extends his attitude to sport and hygiene to his sexual life" - Adorno and Horkheimer, 2008: 109) and the nowadays fully visible "therapeutic style" (Illouz, 2007), issuing in the ideology of wellness and the complete materialism of the globalized sex market ("with the assistance of sex educators, psychoanalysts, and hormone physiologists" - Adorno and Horkheimer, 2008: 109). The libertine is involved in the biopolitical regime of hygiene and sex is turned into a sports activity. The danger of the libertine, copulating across class distinctions in ancient-régime France, is reduced in modern society. Michel Houllebecq's novels portray men (mostly) who are beyond any successful therapeutic methods, and who find them- 
selves sexless in sexualized societies, continuously talking about sex and seductive bodies and thoughts. They solve their problems with alcohol or in swinger clubs, and the more conventional sections of society watch Oprah Winfrey or found fight clubs.

\section{Dialectic of Pornographic Enlightenment}

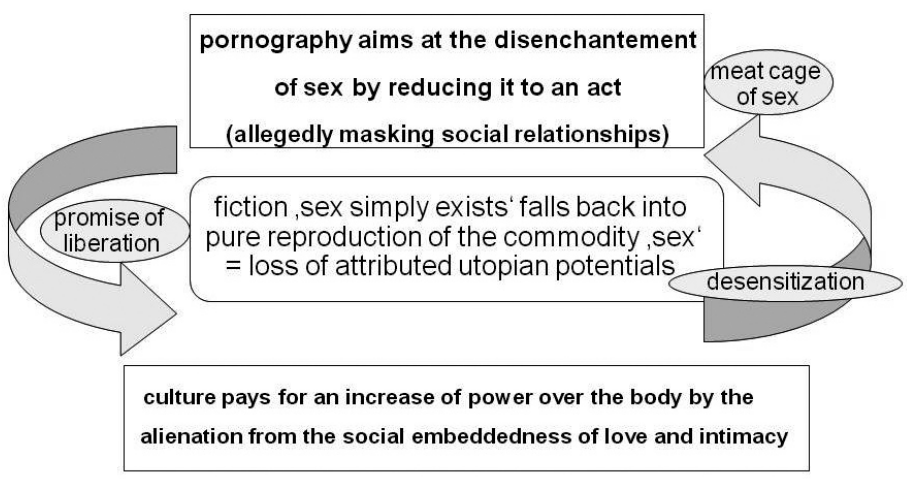

Thirdly, and this is at the same time the starting point for my brief historical overview, Adorno and Horkheimer announce the proximate utopia "which makes sexual pleasure free for all" (Adorno and Horkheimer, 2008: 109) - a utopia that seems to have been realized in the "porno-democratic societies" (Millet, 2002) of the 1990s and after. Now the internet delivers every imaginable fantasy to every home, wherever it might be.

\section{Disciplined Sex, Market-driven Desires: Modern European Pornography}

Looking back at the first two hundred years since the "invention" of modern pornography as we know it today, we can recognize pendulum movements in its development that are analogous to the conceptual shifts of the dialectic discussed above. As Lisa Sigel says, on whose introduction to the volume International Exposure my brief remarks are based, "pornography and the battles about it pinpoint the sexual tensions in society, whether between citizen and subject, man and woman, children and adults, national and global" (Sigel, 2005: 23).

It is important to remember that "pornography" as a broad cultural phenomenon only arose around 1800 . After de Sade, pornography developed from being a politically committed, yet secret form of pleasure, into a customer-oriented, publicly debated and regulated genre. 
In the 1790s, the French Revolution let loose another cascade of pornographic pamphlets directly linked to political conflicts and, at the same time, the early pornographic tradition culminated in the writings of the Marquis de Sade... No one has ever been able to top Sade because he had, in effect, explored the ultimate logical possibility of pornography: the annihilation of the body, the very seat of pleasure, in the name of desire. This ultimate reduction ad absurdum of pornography would not have been possible without the prior establishment of a pornographic tradition. By the early nineteenth century, when efforts at regulation for moral purposes expanded dramatically, the police, the writers, the printers and the readers all knew what the models were (Hunt, 1996: 35).

During the nineteenth century pornography was considered harmful, requiring regulation and the disciplining of the European populations. "By the 1860s most governments, including those in England, France, and Germany, began national campaigns to control their populations through censorship of sexual ideas" (Sigel, 2005: 11-12). The state argued that it had a duty to protect the weak, most of all women, but also people of colour, children and the young. Such views strengthened in the years between 1880 and 1920, partly due to the very conservative morals of the great empires of England (Victorianism), Germany (Wilhelminism) and Austria-Hungary. But they also provoked counter-reactions in the work of artists and scientists, who in the decades around the turn of the century began to develop the modern social sciences. "Consumerism and science formed a reciprocating relationship as pornographers marketed their works according to specific sexual appetites and scientists studied, labeled, categorized, and created etiologies for emerging desires" (Sigel, 2005: 15).

The period after the First World War showed an extreme "cult of the body," with an emphasis on nudity and natural sexuality. As this movement was directed against the effects of industrialized society-including the culture of commerce and consumerism-explicit pornography could not benefit from this liberation but had to be adjusted to express a kind of eroticism, veiled yet appealing enough to excite masturbatory phantasies. The political Right in the shape of National Socialism reinforced this anti-pornographic position, claiming that it was "decadent," even though "Nazi ideals incorporated elements of pornography into public art" (Sigel, 2005: 15).

The growing influence of American culture on western societies brought with it the American way of negotiating sex. Pin-ups, porn films and magazines, such as Playboy, reached the market and, accompanied by the sexual revolution in the 1960s, raised the question of censorship again. European democracies, keen on opposing their new political systems to fascism and communism alike, reversed their social policy and legalized pornography on the basis of the assumption that 
any product or artwork dealing with sexuality and that had a social value should not be censored. This political attitude towards pornography came under pressure once the legalization of pornography kicked off new market developments.

This process occurred twice in the late twentieth century, first during the 1960s and 1970s in Western Europe and then during the 1980s and 1990s in the Eastern bloc. In both instances the political values of pornography lessened as its economics became more pronounced with legalization... As the relaxation over censorship allowed pornography to go mainstream, the 1960s and 1970s seemed to be a "pornographic moment" in Western Europe. The rise of the new Left and the focus on personal liberation resulted in broad acceptance of sexually explicit materials (Sigel, 2005: 16).

This pendulum swing towards an appreciation of the liberating forces of explicit sexual material, together with other hedonistic and individualizing shifts in western culture, prepared the way for a huge expansion in the marketing of pornography. More recently, the technical revolution of the internet has provoked new debates on how to deal with the now pervasive flood of pornographic images and, more theoretically, how to conceive of subjectivity and carnality in this cultural sphere.

\section{Living in "On/scenity"}

Various concepts have been used to describe the overwhelming influence of sexually explicit content in contemporary western societies: "Striptease Culture" (McNair, 2002), "Porno Pop" (Metelmann, 2005), the "Sexualization of Culture" (Attwood, 2006), to name but a few. Linda Williams has coined the very useful term "on/scenity" to express the dialectic between the individual and the new publicity of pornography.

In Latin, the accepted meaning of the obscene is quite literally "offstage," or that which should be kept "out of the public view" (OED). On/ scene is one way of signaling not just that pornographies are proliferating but that once off $(o b)$ scene sexual scenarios have been brought onto the public sphere. On/scenity marks both the controversy and scandal of the increasingly public representations of diverse forms of sexuality and the fact they have become increasingly available to the public at large (Williams, 2004: 3).

I will now focus on the next generation within the framework of the suggested dialectic of pornographic enlightenment. Young people born in the 1990s are the first generation to grow up in an internet society and an expanding "on/scenity." How do they react to the changes in body politics due to the ongoing sexualization of society? And what does society think of this? 
On the one hand, there seems to be a quite natural adaptation to the increased importance of the body and sexual attractiveness. In his research on the MySpace community, the artist and graphic designer Viktor Matic (Matic, forthcoming) discovered a high tendency among the young to incorporate sexually explicit images into their self-presentations (and these images are explicit not only with regard to sex, but also to violence).

But do young people really know what it means to be so apparently "available"? How do young people perceive the relationship between self, subjectivity and sexuality? At least in Germany there is a debate about "Generation Porno," the so-called "forgotten children," the emotionally neglected children of lower-class families (or whatever is left of them). At the age of 13 or 14, many such girls have had up to 200 sexual partners, spending their weekends at "gang-bang" parties, and mostly without using contraceptives. One girl asked the former youth pastor and founder of Arche (a Christian organization for the protection of children and teens) in Berlin, Bernd Siggelkow: "Do you think I'm beautiful?" - "Why are you asking?" - "Because I haven't had sex yet" (Siggelkow and Büscher, 2008: 12). Siggelkow and Büscher, the authors of the book Deutschlands sexuelle Tragödie. Wenn Kinder nicht mehr lernen, was Liebe ist, explicitly blame the "porn plague" and the "hard pictures" freely available on the internet and transmitted via mobile phones as being responsible for an attitude among children that privileges having sex over love, tenderness or trust-concepts and emotions that these kids simply have not learned (2008: 59-65).

I would call this behavioural complex of the "Generation Porno" a form of negative virtual collectivization that leads to the real community of the Arche children. What can be discovered in this report from Berlin is an enormous pressure on both girls and boys in the styling of their sexual selves during adolescence-a hardcore pressure, deriving from the consumption of "real" pornography. The permanent presence of sex and pornography seems to impede any other form of self-concept except the "I'm here for the gang-bang" mode. The "hyper-sexualized society" (Siggelkow and Büscher, 2008: blurb) has colonized minds and emotions. As the young girl just cited testifies: it is not fun to be excluded from the sex community (Gernert, 2010: chapter 1; Gagnon and Simon, 2002).

The classical counter-argument would claim that there have always been precocious children, sex in puberty and class-related porn consumption (Schetsche, 1998: 149-51; Matthiesen and Schmidt, 2009). But two things seem to have changed in remarkable ways. Firstly, the connection between the consumption of images and individual practice, as the links between concrete body politics, sexually explicit images and 
group pressure seem to have become much tighter. Secondly, obscene images of "real sex" have become much more familiar in "porn democratic societies" (Millet, 2002), so that one could argue that in the porn pop era even the young entertain a pornographic relationship with the most intimate representations. Children and adolescents use them as stimulation, training their impulses, in order to show off, and by so doing they transgress societal taboos and annihilate obscenity (Barcan, 2004: 254). “On/scenity" knows no shame (Williams, 2004: 3).

I cannot provide a full discussion of these phenomena here, as I have done elsewhere (Metelmann, forthcoming), but I do want to stress those aspects of disembedded sex - the realization of the pornographic imaginary (Sontag, 1969) - that deprive upcoming generations of their sensual potential. Opposing free and orgiastic sexual behaviour to the forms of intercourse that are framed by a committed and affectionate relationship inscribes an actual societal problem inside the cultural pattern that I have labelled the dialectic of pornographic enlightenment. Though the example of the MySpace community and its sexually explicit selfrepresentation and the fact that the neglected children of the Arche community derive a large part of their self-worth from their sexual activity, are not fully comparable, they do throw light on the underlying cultural logic of how sex is now negotiated, and together demand further research in this field.

Jörg Metelmann is Director of the Leadership Skills program in Contextual Studies at the University of St Gallen, where he is also an adjunct lecturer at the department of Humanities and Social Sciences. His areas of academic specialization include German Literature, Philosophy, Political Science, Media and Cultural Studies. In addition to his work as a freelance journalist, his scholarly publications in the field of Media Studies have focused on Cinema, Pornography, Religion and Surveillance. His current areas of interest include social organization, visual culture and melodrama studies. Together with Scott Loren he is managing a two-year research project on the development of an "aesthetics of irritation," which seeks to repoliticize the notion of subjectivity in narrative and film studies.

\section{BIBLIOGRAPHY}

Adorno, T. W., and M. Horkheimer. 2008 [1944]. Dialectic of Enlightenment. London: Verso.

Attwood, F. 2006. "Sexed Up: Theorizing the Sexualization of Culture." Sexualities 9.1: 77-94. doi:10.1177/1363460706053336

-2007. "No Money Shot? Commerce, Pornography and New Sex Taste Culture." Sexualities 10.4: 441-56. doi:10.1177/1363460707080982 
Barcan, R. 2004. Nudity: A Cultural Anatomy. Oxford: Berg.

Brinkmann, R. D. 1987 [1971]. Erkundungen für die Präzisierung des Gefühls für einen Aufstand: Reise Zeit Magazin [Tagebuch]. Reinbek bei Hamburg: Rowohlt Verlag.

Gagnon, J. H., and W. Simon. 2002. Sexual Conduct: The Social Sources of Human Sexuality. Chicago: Aldine, 2nd edn.

Gernert, J. 2010. Generation Porno. Sex, Lügen, Internet. Köln: Fackelträger Verlag.

Hunt, L. 1996. "Introduction: Obscenity and the Origins of Modernity, 1500-1800." In L. Hunt (ed.), The Invention of Pornography: Obscenity and the Origins of Modernity 1500-1800: 9-45. New York: Zone Books.

Illouz, E. 2007. Cold Intimacies: The Making of Emotional Capitalism. Oxford: Blackwell.

Matic, V. Forthcoming. "15mb fame: Ein Abbild der ersten publish yourself-Ära." In J. Metelmann (ed.), Porno Pop II: Im Erregungsdispositiv. Würzburg: Königshausen \& Neumann.

Matthiesen, S., and G. Schmidt. 2009. “Sexuelle Erfahrungen und Beziehungen adoleszenter Frauen. Qualitative Interviews mit 60 Teenagern, die ungewollt schwanger wurden." Zeitschrift für Sexualforschung 22.2: 97-120. doi:10.1055/s0028-1098931

McNair, B. 2002. Striptease Culture: Sex, Media and the Democratization of Desire. London: Routledge. doi:10.4324/9780203469378

Metelmann, J. 2005. "Flesh for Fantasy. Das Porno-Pop-Format." In J. Metelmann (ed.), Porno Pop: Sex in der Oberflächenwelt: 41-58. Würzburg: Königshausen \& Neumann.

-Forthcoming. “Im Erregungsdispositiv. Vorwort zu Porno Pop II." In J. Metelmann (ed.), Porno Pop II: Im Erregungsdispositiv. Würzburg: Königshausen \& Neumann.

Millet, C. 2002. “Les ecologists du sexe." Le Nouvel Observateur (5 December 2002): 3.

Rushdie, S. 2004. “The East is Blue.” In T. Greenfield-Sanders (ed.), XXX: 30 Porn Star Portraits: 98-105. Boston: Bulfinch.

Schetsche, M. 1998. "Pornographie im Internet. Phänomenologie und Phantomatik." In G. Schmidt and B. Strauss (eds.), Sexualität und Spätmoderne. Über den kulturellen Wandel der Sexualität: 139-58. Stuttgart: Ferndinand Enke.

Sigel, L. Z. 2005. "Introduction: Issues and Problems in the History of Pornography." In L. Z. Sigel (ed.), International Exposure: Perspectives on Modern European Pornography 1800-2000: 1-26. New Brunswick: Rutgers University Press.

Siggelkow, B., and W. Büscher. 2008. Deutschlands sexuelle Tragödie. Wenn Kinder nicht mehr lernen, was Liebe ist. Asslar: Gerth Medien GmbH.

Sontag, S. 1969. "The Pornographic Imagination." In S. Sontag, Styles of Radical Will: 35-73. New York: Farrar.

Vinken, B. 1995. “Vorwort: Das Gesetz des Begehrens-Männer, Frauen, Pornographie." In D. Cornell, Die Versuchung der Pornographie: 7-22. Berlin: Berlin Verlag.

Williams, L. 2004. "Porn Studies: Proliferating Pornographies On/Scene. An Introduction." In L. Williams (ed.), Porn Studies: 1-23. Durham: Duke University Press.

-2008. Screening Sex. Durham: Duke University Press. 